\title{
Properties of Fly Ashes from Thermal Power Stations in Relation to Use as Soil Amendments
}

(Sifat Abu Cerobong dari Stesen Janakuasa Terma yang Berkaitan dengan Kegunaan sebagai Pindaan Tanah)

\author{
Le VAn Thien*, Ngo Thi Tuong Chau, Le Thi Tham Hong, Nguyen Thu Trang \& Hiroyuki Futamata
}

\begin{abstract}
Recycling fly ashes is a good alternative to disposal with the significant economic and environmental benefits. Characterization of fly ashes can be helpful to evaluate their use potentials. This study aimed to investigate the physical, chemical and mineralogical properties of fly ashes from five thermal power stations in Northern Vietnam in relation to use as sandy soil amendments. The results showed that the fly ashes were dominated by silt-sized and spherical particles and had low bulk densities. There was almost not significant difference in the surface charges among the fly ashes; however, their surface areas varied widely. The fly ashes were alkaline. The electrical conductivity and cation exchange capacity in the fly ashes were higher than those in the sandy soil. The concentrations of extractable $\mathrm{K}, \mathrm{P}, \mathrm{Ca}^{2+}$ and $\mathrm{Mg}^{2+}$ in the fly ashes were higher compared with the sandy soil. The major matrix elements in the fly ashes were Si, Al, and Fe together with significant percentages of $\mathrm{K}, \mathrm{Mg}, \mathrm{Ca}$ and $\mathrm{Ti}$. Quartz was the most predominant mineral present in the fly ashes. Several radioactive elements were found in the fly ashes with very low concentrations. The potential to release trace elements from the fly ashes was below the regulatory guidelines. The amendment of fly ashes to the sandy soil led to the substantial decrease in the hydraulic conductivity but the increase in the plant-available water contents of the sandy soil. It is recommended to use the fly ashes as soil amendments for sandy soil amelioration.
\end{abstract}

Keywords: Fly ash; sandy soil; soil amelioration; soil amendment; thermal power station

ABSTRAK

Mengitar semula abu cerobong adalah alternatif pelupusan yang baik daripada sudut ekonomi dan alam sekitar. Pencirian abu cerobong membantu untuk menilai potensi kegunaannya. Kajian ini dijalankan untuk mengkaji sifat fizikal, kimia dan mineralogi abu cerobong dari lima stesen janakuasa haba di Vietnam Utara yang berkait dengan pemindahan tanah berpasir. Keputusan kajian menunjukkan bahawa abu cerobong didominasi oleh zarah yang bersaiz kelodak dan sfera dan mempunyai ketumpatan pukal yang rendah. Tiada perbezaan yang ketara pada cas permukaan bagi abu cerobong namun luas kawasan permukaannya adalah berbeza. Abu cerobong bersifat alkali. Kekonduksian elektrik dan kapasiti pertukaran kation abu cerobong lebih tinggi berbanding tanah berpasir. Kepekatan $\mathrm{K}, \mathrm{P}, \mathrm{Ca}^{2}+\mathrm{dan}_{\mathrm{Mg}}{ }^{2+}$ terekstrak di dalam abu cerobong lebih tinggi berbanding tanah berpasir. Unsur matriks utama dalam abu cerobong adalah Si, Al dan Fe berserta peratusan besar bagi unsur K, Ca, Mg dan Ti. Kuarza adalah mineral pradominan dalam abu cerobong. Beberapa unsur radioaktif ditemui dalam abu cerobong dengan kepekatan yang sangat rendah. Potensi untuk melepaskan unsur-unsur surih daripada abu cerobong adalah di bawah dasar garis panduan. Pindaan abu cerobong ke tanah berpasir membawa kepada penurunan ketara kekonduksian hidraulik tetapi peningkatan kandungan air yang terdapat dalam tanah berpasir. Adalah disarankan untuk menggunakan abu cerobong sebagai pindaan tanah untuk ameliorasi tanah berpasir.

Kata kunci: Abu cerobong; ameliorasi tanah; pindaan tanah; stesen janakuasa haba; tanah berpasir

\section{INTRODUCTION}

Fly ash is a by-product of coal combustion at high temperatures in thermal power stations. Ahmaruzzaman (2010) reported that the annual production of coal ash worldwide was estimated around 600 million tonnes, with fly ash constituting approximately 500 million tonnes at $75-80 \%$ of total ash produced. A large part of this fly ash is land filled and surface impounded, with potential risks of air pollution and contamination of water due to leaching (Femández-Jiménez \& Palomo 2005). Therefore, disposal of fly ash is one of the major environmental challenges.
This challenge continues to increase with increasing the amount of fly ash and decreasing the capacity of landfill space. However, fly ash should not only be disposed of safely to prevent environmental pollution, but should be treated as a valuable resource. Fly ash can be used in the construction industry viz. production of geopolymer cement possessing properties superior to ordinary Portland cement (Ma et al. 2016; Okoye et al. 2015; Onutai et al. 2015), preparation of cement composite binder (Fediuk \& Yushin 2015), partial replacement of cement in traditional paste/mortar/concrete mixtures 
based on Portland cement (Rashad 2015), and road base construction (Yao et al.2015). Other uses include zeolite synthesis (Chansiriwat et al. 2016; Izidoro et al. 2012), soil amelioration (Ram \& Masto 2014), mine reclamation (Ram \& Masto 2010; Skousen et al. 2012), alumina and cenosphere recovery (Kolay \& Bhusal 2014; Yao et al. 2014), adsorbents for mercury removal (Zheng et al. 2012), and ceramic industry (Yao et al. 2015). However, only a small part of total fly ash produced is used (20$30 \%$ ) and fly ash is still identified as a significantly underutilized resource (Ukwattage et al. 2013). In terms of soil amelioration, fly ash is a useful soil additive especially for low nutrient poorly structured soils. Hence, for the sandy soils which pose a particular challenge for water and nutrient management due to their low ionic adsorption capacities and high hydraulic conductivities (Pathan et al. 2001), fly ash creates a possible solution to improve soil quality and crop yields. In fact, the improved sandy soil quality and increased crop growth were shown after the addition of fly ash by increasing soil water holding capacity and improving nutritional status (Pandey \& Singh 2010; Ram et al. 2007). However, since almost all naturally existing elements are present in fly ash (Summers et al. 1998), the potential release of trace elements may also be an issue determining the suitability of fly ashes for use as a soil amendment. The physical, chemical and mineralogical properties of a particular fly ash are dependent on the composition of the parent coal, conditions during coal combustion, efficiency of emission control devices and practices used during storage and handling (Adriano et al. 1980). It proposes the necessity of having a thorough understanding on the properties of fly ash before any soil amelioration application to derive the expected results out of it. Although the research literature contains numerous reviews on the use of fly ash in degraded soil reclamation (Ukwattage et al. 2013), there is only a piecemeal understanding of possible use of fly ash in crop soils, especially sandy soils. Therefore, this study aimed to assess the physical, chemical and mineralogical properties of fly ashes from five thermal power stations in Northern Vietnam in relation to use as soil amendments for sandy soil amelioration in Central Vietnam.

\section{Materials AND Methods}

\section{FLY ASH COLLECTION}

The fly ashes were collected from the dumping sites of five thermal power stations Pha Lai, Mong Duong I, Mong Duong II, Ha Khanh and Ninh Binh in Northern Vietnam (hereafter referred to as 'Pha Lai, Mong Duong I, Mong Duong II, Ha Khanh and Ninh Binh fly ashes'). The parental coal source of fly ashes was Quang Ninh (Vietnam) anthracite, except the anthracite mixed with Indonesia sub-bituminus coal for Ninh Binh fly ash. Anthracite is a hard, compact variety of mineral coals that has a high lustre. It has the highest carbon count and contains the fewest impurities of all coals despite its lower calorific content (Basu et al. 2009). Pha Lai, Mong Duong II, Ha Khanh and Ninh Binh fly ashes were derived from the pulverized fuel coal combustion while Mong Duong I was derived from the fluidized bed combustion. The fly ashes were captured by the emission control devices (electrostatic precipitators). The sandy soil was collected from Le Thuy District, Quang Binh Province, Central Vietnam. The fly ashes were thoroughly while the sandy soil was air-dried for 5 days, passed through a $2.0-\mathrm{mm}$ mesh sieve and stored plastic-lined containers at room temperature prior to use.

\section{DETERMINATION OF PHYSICAL PROPERTIES}

The particle size distribution of fly ash was determined with a laser scattering particles size distribution spectrometer (LA 950V2, Horiba, Japan). The morphology of fly ash particles was observed and measured with a scanning electron microscope (FEI Nova NanoSEM 450, USA). The bulk density of sandy soil was measured with a soil sampler of known volume to collect intact cores, which were ovendried and weighed (Blake \& Hartge 1986). The fly ash was firmly packed in a cylinder and then its bulk density was measured as for the sandy soil. The surface charges of fly ash and sandy soil were measured with a particle charge detector (Mütek PCD-05, Germany). The surface areas of fly ash and sandy soil were determined by the BrunauerEmmett-Teller (BET) nitrogen adsorption with a surface area analyzer (Micromeritics Gemini VII, USA). The fly ash, sandy soil and mixtures of fly ash with sandy soil (5, 10, 20 and $50 \% \mathrm{w} / \mathrm{w}$ ) were firmly packed into Buchner funnels, then hydraulic conductivities were measured by the constant head test method (Klute \& Dirksen 1986). Their contents of plant-available water were defined as water released between matric potentials of $-5 \mathrm{KPa}$ (field capacity) and $-1500 \mathrm{KPa}$ (wilting point).

\section{DETERMINATION OF CHEMICAL PROPERTIES}

The $\mathrm{pH}$ of $1 \mathrm{~N} \mathrm{KCl}$ after being mixed with the fly ash or the sandy soil $(1: 5 \mathrm{w} / \mathrm{v})$ and electrical conductivity (EC) of extracts in deionized water $(1: 5 \mathrm{w} / \mathrm{v})$ were measured with a $\mathrm{pH}$ and EC meter. The cation exchange capacity (CEC) was determined by the ammonium acetate method at neutral $\mathrm{pH}$ value (TCVN 8568:2010). Total carbon (C) after dry combustion was determined according to TCVN 66422000 (ISO 10694:1995). Total nitrogen (N) was determined by the modified Kjeldahl method (TCVN 6498:1999- ISO 11261:1995). Extractable phosphore (P) in the sample shaken in $0.05 \mathrm{M} \mathrm{H}_{2} \mathrm{SO}_{4}$ for 5 min was determined by the colorimetry method (TCVN 5256:2009). Extractable potassium $(\mathrm{K})$ in the sample shaken in $1.0 \mathrm{M} \mathrm{CH}_{3} \mathrm{COONH}_{4}$ (pH7.0) was measured with Flame AAS (TCVN 8662: 2011). Total calcium ions $\left(\mathrm{Ca}^{2+}\right)$ and magnesium ions $\left(\mathrm{Mg}^{2+}\right)$ was determined with the titration of $\mathrm{Ca}^{2+}, \mathrm{Mg}^{2+}$ by Trilon $\mathrm{B}$ titrant (TCVN 4406-87). 

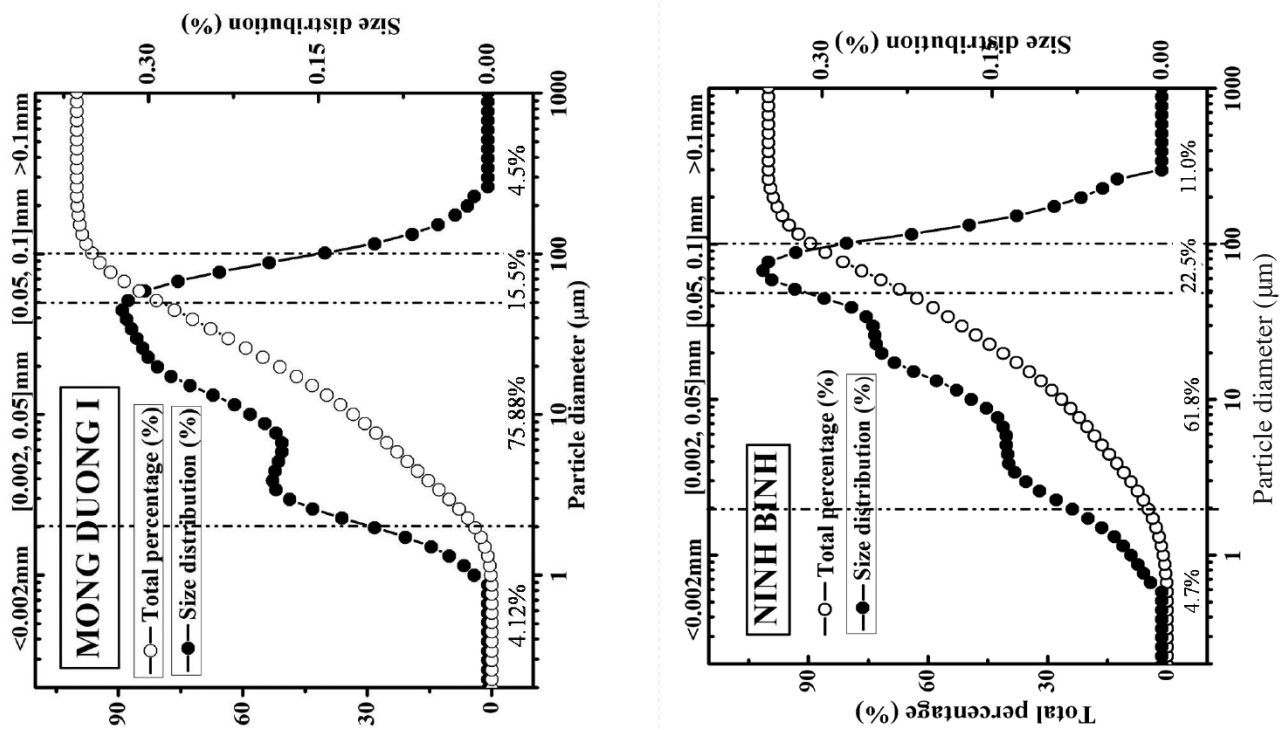

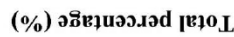
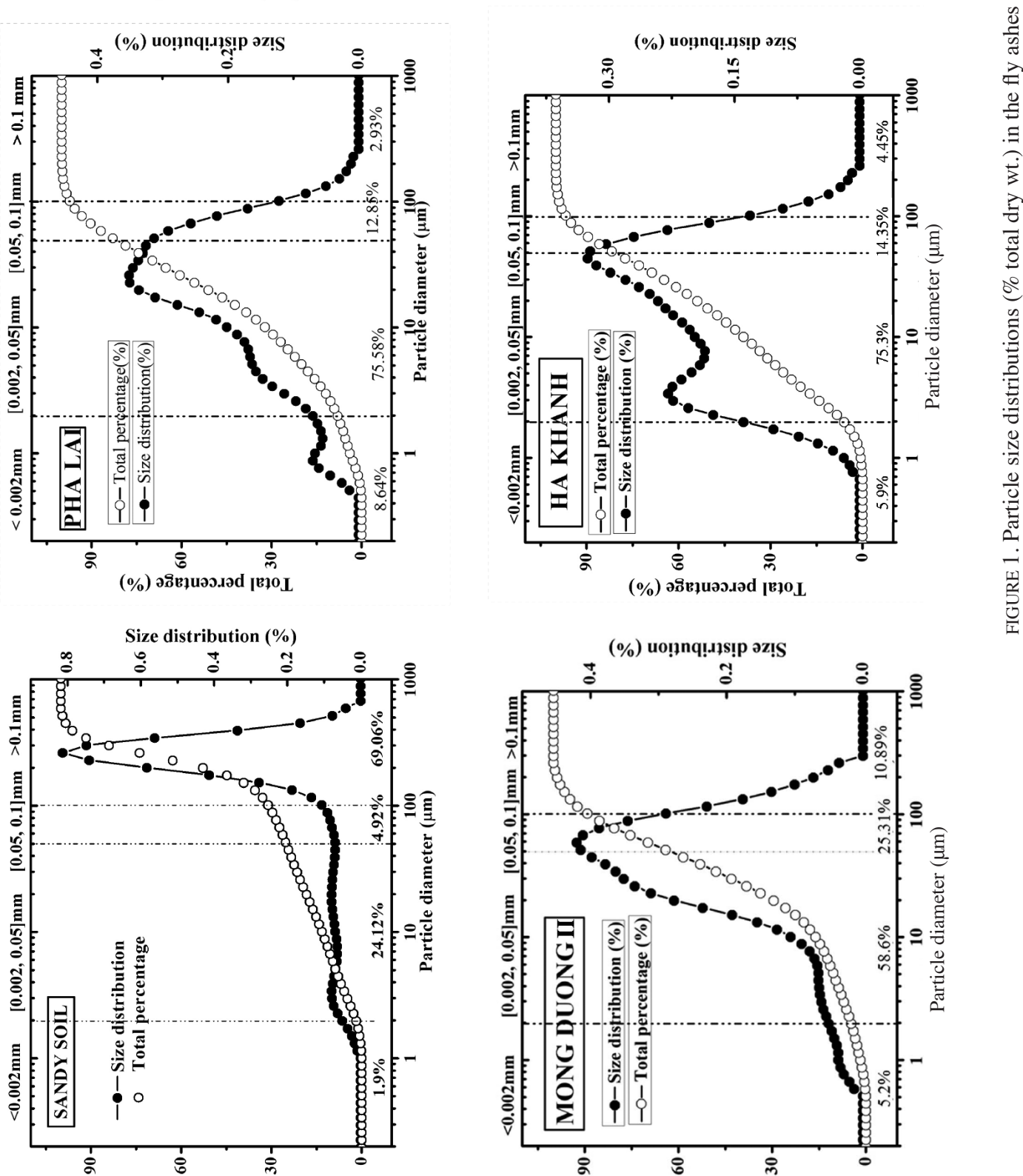

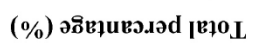

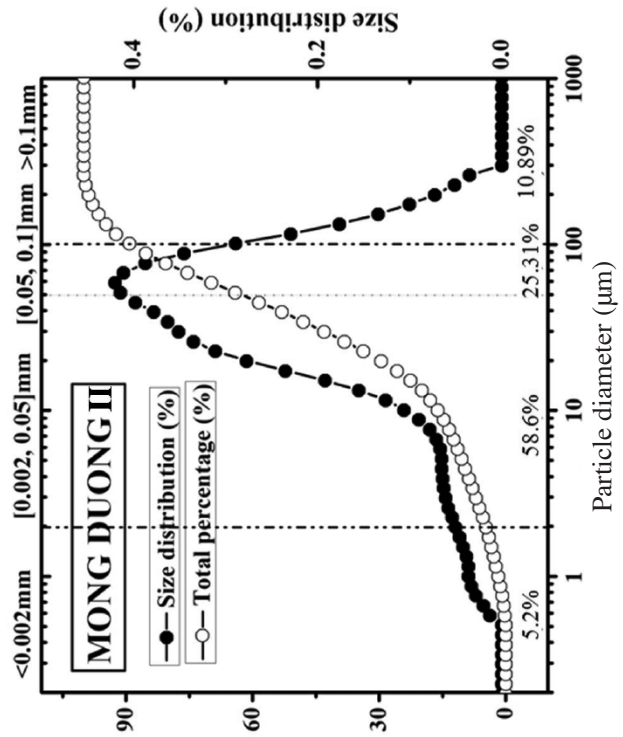

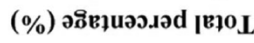


DETERMINATION OF CHEMICAL AND MINERALOGICAL COMPOSITIONS OF FLY ASH

The elemental composition was determined using particle induce X-ray emission (PIXE) with a Model 5SDH-2 Pelletron Accelerator (NEC, USA). The composition of oxides of elements was determined with energy dispersive X-ray fluorescence spectrometer (Shimadzu-1800, Japan). The mineralogical composition of fly ash was quantified with a X-ray diffractometer (XRD) (SIEMENS D5005 Bruker, Germany). The radioactive elements of fly ash $\left({ }^{226} \mathrm{Ra},{ }^{238} \mathrm{U}\right.$, ${ }^{232} \mathrm{Th}$ and ${ }^{40} \mathrm{~K}$ ) were quantified with a gamma spectroscopy (ORTEC GEM-30, USA). According to TCVN 10302:2014, the effective specific activity of natural radioactive nuclides of fly ash $\left(\mathrm{A}_{\text {eff }}, \mathrm{Bq} \mathrm{kg}{ }^{-1}\right)$ was calculated using the following equation: $\mathrm{A}_{\text {eff }}=\mathrm{A}_{\mathrm{Ra}}+1.31 \mathrm{~A}_{\mathrm{Th}}+0.085 \mathrm{~A}_{\mathrm{K}}$, where $\mathrm{A}_{\mathrm{Ra}}, \mathrm{A}_{\mathrm{Th}}$ and $A_{K}$ are the specific activities of ${ }^{226} \mathrm{Ra},{ }^{232} \mathrm{Th}$ and ${ }^{40} \mathrm{~K}$ of fly ash (in $\mathrm{Bq} \mathrm{kg}^{-1}$ ).

\section{INVESTIGATION OF POTENTIAL FOR RELEASE} OF TRACE ELEMENTS

The toxicity characteristic leaching procedure (TCLP) was used to determine the amounts of trace elements that could potentially leach from the fly ash and sandy soil. Briefly, the samples were mixed with $0.57 \%$ glacial acetic acid (1:20 $\mathrm{w} / \mathrm{v} ; \mathrm{pH}$ approximately 2.88) and extracted according to the standard procedures (USEPA 1992). Subsequently, the trace elements in the extraction were measured with ICP/ MS system (PerkinElmer Elan 9000, USA).

\section{RESULTS AND DISCUSSION}

\section{PHYSICAL PROPERTIES}

The physical properties of fly-ash vary widely depending on the coal type, boiler type, ash content in coal, combustion method and collector setup (Ukwattage et al. 2013). In this study, according to the particle-size distribution of USDA (2017), the fly ashes were primarily silt-sized particles $(0.002-0.05 \mathrm{~mm})$ and fine sand-sized particles $(0.05-0.1$ $\mathrm{mm})$. This result is consistent with the view that fly ashes are usually dominated by silt-sized particles (Adriano et al. 1980; Aitken et al. 1984; Ghodrati et al. 1995; Pathan et al. 2003; Pavey \& Singh 2010). The proportion of the silt-sized particles ranged from 58.60 to $75.88 \%$ and the sand-sized particles ranged from 12.85 to $25.31 \%$ (Figure 1). Pha Lai fly ash was finest among the fly ashes. In contrast, the sandy soil was primarily coarse sand-sized particles $(>1.0 \mathrm{~mm})$ with the proportion of $69.06 \%$ (Figure 1). Since the high percentage of silt-size particles in the fly ashes, the largescale applications of fly ash into the sandy soil tend to change the soil texture (soil bulk density) by increasing silt content. Besides, Pha Lai, Mong Duong II and Ninh Binh fly ashes composed of mostly regular spherical particles (1-8 $\mu \mathrm{m}$ in diameter) while Mong Duong I and Ha Khanh fly ashes were amorphous in particle shape (Figure 2). Similar result has been reported by Swamy and Lambert (1981), who described fly ash composed of mostly fine and spherical particles.

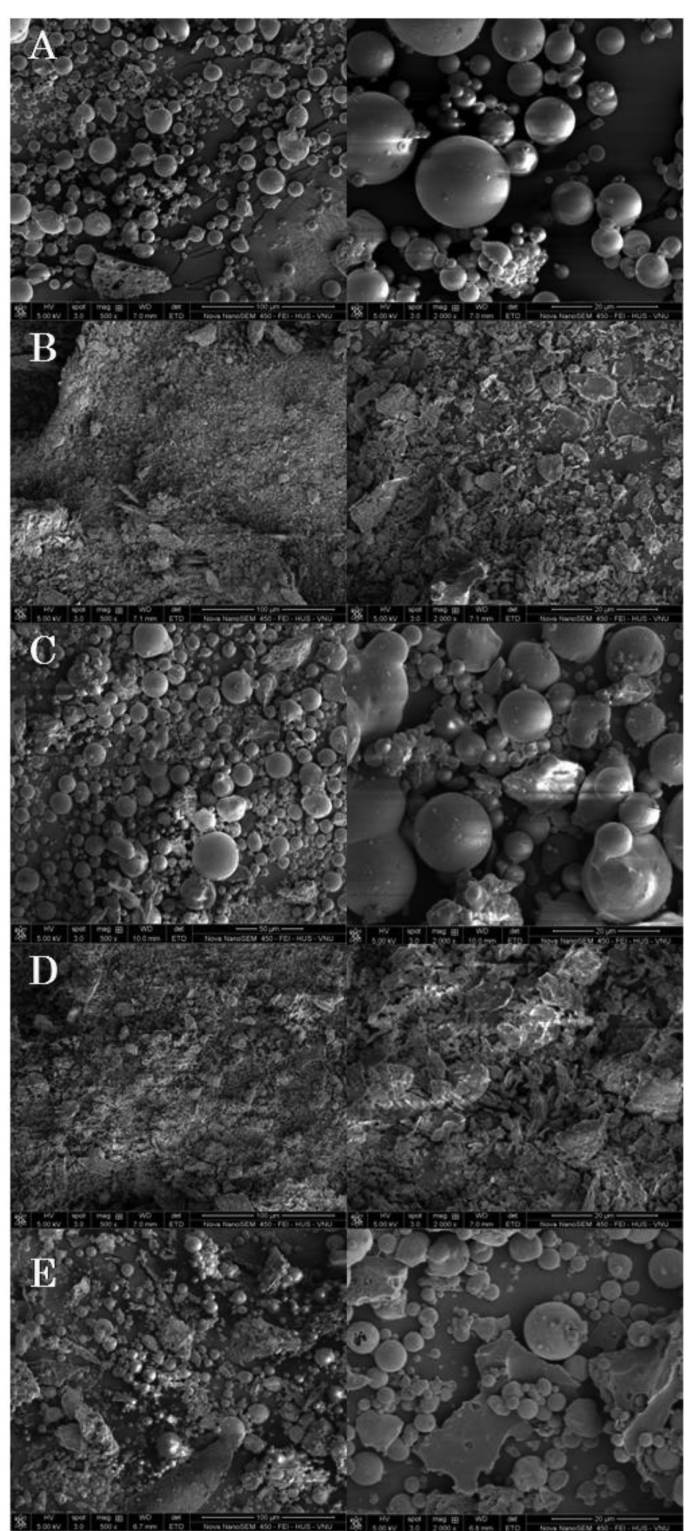

FIGURE 2. SEM micrographs of Pha Lai (A), Mong Duong I (B), Mong Duong II (C), Ha Khanh (D), and Ninh Binh (E) fly ashes $(\times 500$ on the left and $\times 2000$ on the right)

Also, as shown in Table 1, the bulk densities, surface charges and surface areas of the fly ashes almost support the notion that fly ashes are low bulk densities and high specific surface areas (Asokan et al. 2005; Jala \& Goyal 2006). The fly ashes had low bulk densities ranging from 0.82 to $1.02 \mathrm{~g}$ $\mathrm{cm}^{-3}$ which were 1.2 to 1.5 - fold lower than the sandy soil. Therefore, these fly ashes are suitable additive to decrease the bulk density of sandy soil in a mixture. On the other hand, the surface charges were not significant differences among the fly ashes $\left(0.12-0.16 \mathrm{~mol} \mathrm{~kg}^{-1}\right)$ except Ninh Binh fly ash $\left(0.23 \mathrm{~mol} \mathrm{~kg}^{-1}\right)$; however, their surface areas varied significantly from 1.68 to $12.10 \mathrm{~m}^{2} \mathrm{~g}^{-1}$. It is similar to the result reported by Aitken et al. (1984) that the surface areas are quite variable among different sources of Australian fly ash. The surface charges and surface areas of the fly ashes were significant different from those of the sandy 
soil. The surface charges and surface areas of the fly ashes were 30 to 57.5-fold higher and 6.0 to 43.2- fold higher than the sandy soil (Table 1). These were very important properties because of their influences on the interaction degree of nutrient ions in soil solution with solid matrix (Fisher et al. 1976).

\section{CHEMICAL PROPERTIES}

The factors influencing the physical properties are also responsible for wide variation of chemical properties of fly ash (Basu et al. 2009). In this study, there was considerable variation of chemical properties among the fly ashes and between the fly ashes and the sandy soil (Table 2).

The $\mathrm{pH}$ of fly ash depends largely on the source, especially the $\mathrm{S}, \mathrm{Ca}$ and $\mathrm{Mg}$ contents of the parental coal. As shown in Table 2, all fly ashes were alkaline $\left(\mathrm{pH}_{\mathrm{KCl}}>9\right)$ with the $\mathrm{pH}$ values in 1:5 (v/w) $1 \mathrm{~N} \mathrm{KCl}$ extracts of fly ashes ranged from 9.1 to 12.3 . Of them, Mong Duong I the fly ash derived from the circulating fluidizing bed combustion using $\mathrm{CaCO}_{3}$ powder to reduce $\mathrm{SO}_{2}$ released from coal combusion was most alkaline. On the contrary, the sandy soil was acidic $\left(\mathrm{pH}_{\mathrm{KCl}} 4.8\right)$. Therefore, the increase in $\mathrm{pH}$ of the acidic sandy soil can be achieved when amended with these fly ashes (Cetin \& Pehlivan 2007; Yao et al. 2015) which in turn, decreases the mobility and availability of heavy metals in the soil (Kishor et al. 2010). Besides, EC values in 1:5 (v/w) $\mathrm{H}_{2} \mathrm{O}$ extracts of the fly ashes ranged from 0.15 to 2.67 $\mathrm{dS} \mathrm{m} \mathrm{m}^{-1}$ and were 3.8 to 66.8 - fold higher than the sandy soil (Table 2). It may be due to the different contents of soluble salts among the fly ashes and the presence of a higher content of soluble salts in the fly ashes compared to the sandy soil. Furthermore, CEC values of the fly ashes were found to be from 8.28 to $10.24 \mathrm{mg} \mathrm{kg}^{-1}$ and 2.2 to 2.7-fold higher compared to the sandy soil (Table 2 ). The fly ashes with higher CEC values could be expected to aid the retention and availability of cationic plant nutrients in the sandy soil when added with fly ash (Summers et al. 1998). Moreover, the extractable K concentrations in the fly ashes varied from 164.1 to $397.9 \mathrm{mg} \mathrm{kg}^{-1}$ and were 12.8 to 31.1 - fold higher than in the sandy soil. The extractable $\mathrm{P}$ concentrations in the fly ashes ranged from 86.1 to $228.6 \mathrm{mg} \mathrm{kg}^{-1}$ and were 7.8 to 20.6 - fold higher than in the sandy soil (Table 2). The high concentrations of extractable $\mathrm{P}$ in the fly ashes may provide plant-available $\mathrm{P}$ for the sandy soil amended with the fly ashes (Summers et al. 1998). The concentrations of $\mathrm{Ca}^{2+}$ and $\mathrm{Mg}^{2+}$ in the fly ashes varied from 5.06 to $8.13 \mathrm{mg} \mathrm{kg}^{-1}$ and 0.84 to 1.63 $\mathrm{mg} \mathrm{kg}^{-1}$ (Table 2). Furthermore, the fly ashes contained negligible amounts of carbon (about $1 \%$ ) and nitrogen (0.1-0.3\%) due to their oxidation during combustion that drastically reduced their quantity in fly ash (Table 2). Hence, the deficient contents of $\mathrm{C}$ and $\mathrm{N}$ in fly ash have to be amended along with fly ash application to soils to enhance the efficiency of fly ash (Yao et al. 2015).

\section{CHEMICAL COMPOSITION OF FLY ASHES}

The composition of elements detected in all fly ashes were $\mathrm{Si}, \mathrm{Al}, \mathrm{Fe}, \mathrm{Mg}, \mathrm{K}, \mathrm{Ca}, \mathrm{P}, \mathrm{S}, \mathrm{Ti}, \mathrm{Cr}, \mathrm{Mn}, \mathrm{Ni}, \mathrm{Cu}, \mathrm{Zn}$ and $\mathrm{Rb}$, with the highest percentages of $\mathrm{Si}, \mathrm{Al}$ and $\mathrm{Fe}$, and significant percentages of $\mathrm{Mg}, \mathrm{K}$ and $\mathrm{Ca}$ (Table 3). Besides, $\mathrm{Cl}$ was not detected in Pha Lai and Ha Khanh

TABLE 1 . Surface charges and surface areas of the fly ashes and sandy soil

\begin{tabular}{llccc}
\hline Sample & & $\begin{array}{c}\text { Bulk density } \\
\left(\mathrm{g} \mathrm{cm}^{-3}\right)\end{array}$ & $\begin{array}{c}\text { Surface charge } \\
\left(\mathrm{mol} \mathrm{kg}^{-1}\right)\end{array}$ & $\begin{array}{c}\text { Surface area } \\
\left(\mathrm{m}^{2} \mathrm{~g}^{-1}\right)\end{array}$ \\
\hline \multirow{6}{*}{ Fly ash } & Pha Lai & $0.86 \pm 0.01$ & $0.15 \pm 0.02$ & $1.81 \pm 0.02$ \\
& Mong Duong I & $0.95 \pm 0.02$ & $0.16 \pm 0.03$ & $8.93 \pm 0.11$ \\
& Mong Duong II & $0.82 \pm 0.01$ & $0.12 \pm 0.01$ & $1.68 \pm 0.01$ \\
Sandy soil & Ha Khanh & $1.02 \pm 0.02$ & $0.14 \pm 0.02$ & $12.10 \pm 0.14$ \\
& Ninh Binh & $0.91 \pm 0.03$ & $0.23 \pm 0.01$ & $8.47 \pm 0.09$ \\
\hline
\end{tabular}

Data given are means of three replicates \pm standard errors. ANOVA was conducted on the data set (significance level $p<0.05$ )

TABLE 2. Some chemical properties of the fly ashes and sandy soil

\begin{tabular}{|c|c|c|c|c|c|c|c|c|}
\hline \multicolumn{2}{|l|}{ Samples } & \multirow{2}{*}{$\begin{array}{c}\mathrm{pH} \\
1: 5 \mathrm{KCl} \\
9.7\end{array}$} & \multirow{2}{*}{ 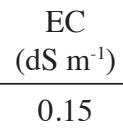 } & \multirow{2}{*}{$\begin{array}{c}\begin{array}{c}\mathrm{CEC} \\
\left(\mathrm{cmol} \mathrm{kg}^{-1}\right)\end{array} \\
8.44\end{array}$} & \multirow{2}{*}{$\begin{array}{c}\begin{array}{c}\text { Extractable P } \\
\left(\mathrm{mg} \mathrm{kg}^{-1}\right)\end{array} \\
112.4\end{array}$} & \multirow{2}{*}{$\begin{array}{c}\begin{array}{c}\text { Extractable K } \\
\left(\mathrm{mg} \mathrm{kg}^{-1}\right)\end{array} \\
397.9\end{array}$} & \multirow{2}{*}{$\begin{array}{c}\begin{array}{c}\mathrm{Ca}^{2+} \\
\left(\mathrm{mg} \mathrm{kg}^{-1}\right)\end{array} \\
5.26\end{array}$} & \multirow{2}{*}{$\begin{array}{c}\begin{array}{c}\mathrm{Mg}^{2+} \\
\left(\mathrm{mg} \mathrm{kg}^{-1}\right)\end{array} \\
0.88\end{array}$} \\
\hline \multirow{5}{*}{ Fly ash } & Pha Lai & & & & & & & \\
\hline & Mong Duong I & 12.1 & 2.67 & 10.24 & 86.1 & 164,1 & 8.13 & 0.86 \\
\hline & Mong Duong II & 9.9 & 0.26 & 8.46 & 141.1 & 369.9 & 5.06 & 0.84 \\
\hline & Ha Khanh & 9.1 & 1.27 & 8.28 & 228.6 & 190.8 & 5.69 & 1.23 \\
\hline & Ninh Binh & 9.4 & 0.24 & 8.68 & 150.8 & 383.1 & 6.12 & 1.63 \\
\hline \multicolumn{2}{|c|}{ Sandy soil } & 4.8 & 0.04 & 3.75 & 11.1 & 12.8 & 0.15 & 0.10 \\
\hline
\end{tabular}

Data given are means of three replicates 


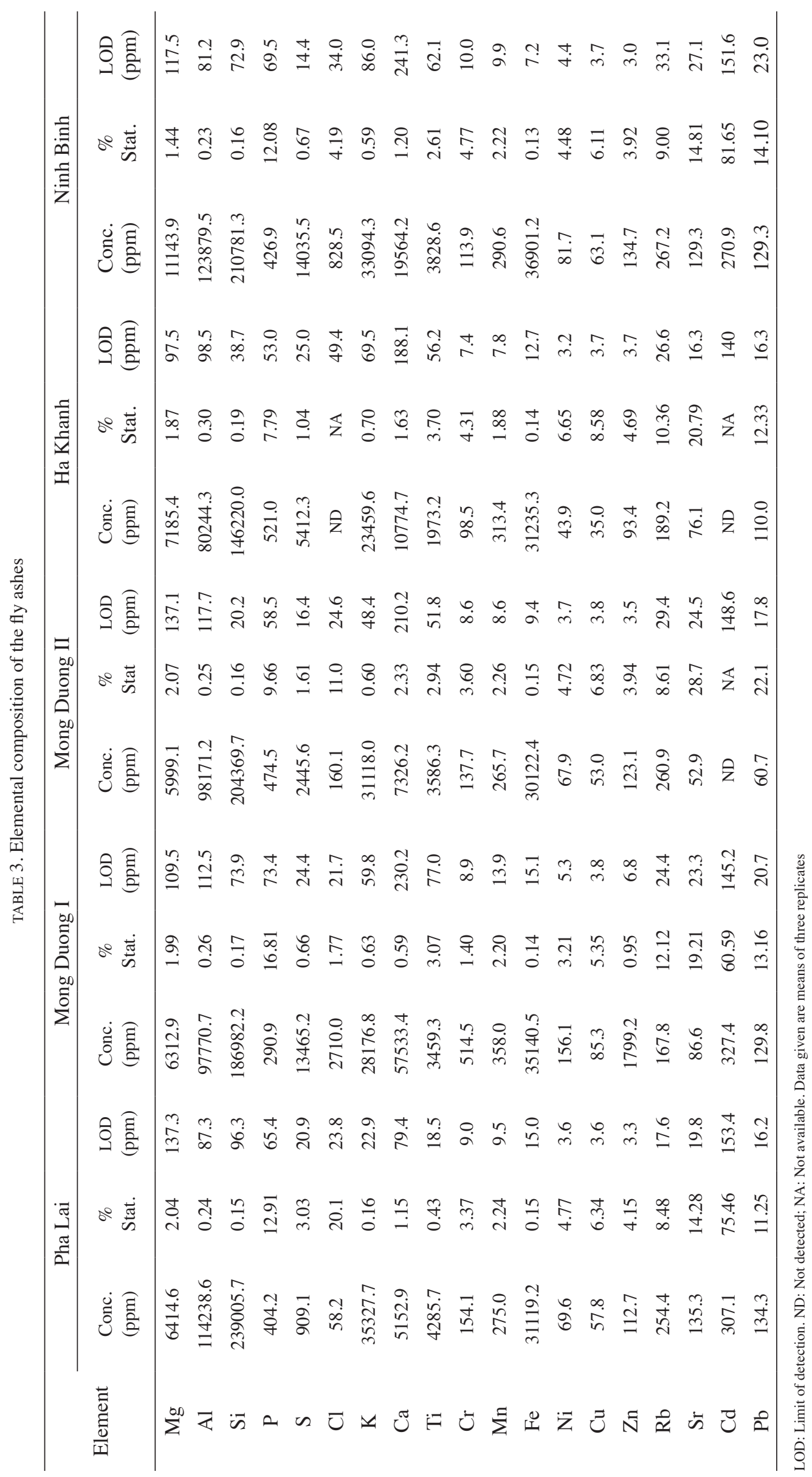


fly ashes, whereas $\mathrm{Sr}$ and $\mathrm{Pb}$ were not detected in Mong Duong II fly ash. The highest content of Al $(123,879.5$ ppm) and Si (239,005.7 ppm) were found in Pha Lai and Ninh Binh fly ashes. Some essential macro-nutrients like $\mathrm{P}, \mathrm{K}, \mathrm{Ca}, \mathrm{Mg}$ and $\mathrm{S}$ and micro-nutrients like $\mathrm{Fe}, \mathrm{Mn}, \mathrm{Zn}$ and $\mathrm{Cu}$ present in fly ashes are beneficial for the plant growth (Yao et al. 2015). However, other metals can be toxic to the plants (Inam 2007). The results of XRF study (Table 4) showed that the major oxide components were $\mathrm{SiO}_{2}, \mathrm{Al}_{2} \mathrm{O}_{3}, \mathrm{~K}_{2} \mathrm{O}$, and $\mathrm{Fe}_{2} \mathrm{O}_{3}$ in Pha Lai, Mong Duong II and Ha Khanh fly ashes; $\mathrm{SiO}_{2}, \mathrm{Al}_{2} \mathrm{O}_{3}, \mathrm{CaO}, \mathrm{K}_{2} \mathrm{O}$ and $\mathrm{Fe}_{2} \mathrm{O}_{3}$ in Mong Duong I fly ash; and $\mathrm{SiO}_{2}, \mathrm{Al}_{2} \mathrm{O}_{3}, \mathrm{Fe}_{2} \mathrm{O}_{3}$ and $\mathrm{K}_{2} \mathrm{O}$ in Ninh Binh fly ash. Accordingly, Ninh Binh fly ash is agreed with the report of Iyer and Scott (2001) that silica, alumina and iron oxide are the primary components of the fly ash matrix. The mass ratio of $\mathrm{SiO}_{2} / \mathrm{Al}_{2} \mathrm{O}_{3}$ in Pha Lai, Mong Duong I, Mong Duong II, Ha Khanh and Ninh Binh fly ashes were 2.39, 1.78, 2.16, 1.79 and 2.15, respectively. Every fly ash had higher mass ratio of $\mathrm{SiO}_{2} /$ $\mathrm{Al}_{2} \mathrm{O}_{3}$ than Saudi Arabia fly ash (1.24) but had lower mass ratio of $\mathrm{SiO}_{2} / \mathrm{Al}_{2} \mathrm{O}_{3}$ than Thailand fly ash (4.35). Notably, the mass ratios of $\mathrm{SiO}_{2} / \mathrm{Al}_{2} \mathrm{O}_{3}$ in Pha Lai, Mong Duong II and Ninh Binh fly ashes was similar to that in Malaysia fly ash (2.21) (Nizar et al. 2014). On the basis of XRD study, it can be stated that the major crystalline phase in the fly ashes was quartz $\left(\mathrm{SiO}_{2}\right)$ (Figure 3$)$. The other crystalline phases in the fly ashes, present in small amounts, were mullite $\left(\mathrm{Al}_{6} \mathrm{Si}_{2} \mathrm{O}_{13}\right)$ and hematite $\left(\mathrm{Fe}_{2} \mathrm{O}_{3}\right)$. In addition, $\mathrm{Ha}$ Khanh fly ash contained muscovite $\left(\mathrm{H}_{2} \mathrm{KAl}_{3} \mathrm{Si}_{3} \mathrm{O}_{12}\right)$ and Mong Duong I fly ash contained muscovite $\left(\mathrm{H}_{2} \mathrm{KAl}_{3} \mathrm{Si}_{3} \mathrm{O}_{12}\right)$ and calcite $\left(\mathrm{CaCO}_{3}\right)$. Hodgson and Holliday (1966) also reported that fly-ash contained minerals such as quartz, mullite and hematite, magnetite, calcite and borax. The presence of calcite in Mong Duong I fly ash may be due to the use of $\mathrm{CaCO}_{3}$ powder to reduce $\mathrm{SO}_{2}$ released from coal combustion with the circulating fluidizing bed technology. The $\mathrm{SiO}_{2}$ presents as quartz or in the crystalline aluminosilucates phases is inert. Similarly, the part of the alumina in the crystalline phase is inactive. Therefore, there is a limited potential for Al toxicity since it is present in fly ash as an aluminosilicate complex form that is not readily available to plants. On the other hand, acceptable radioactivity levels in addition to other environmental factors is a key factor for safe utilization of fly ash. In this study, the quite low concentrations of the radioactive elements $\left({ }^{226} \mathrm{Ra},{ }^{238} \mathrm{U},{ }^{232} \mathrm{Th}\right.$ and $\left.{ }^{40} \mathrm{~K}\right)$ were found in the fly ashes (Figure 4). Similar result also reported by Bhangare et al. (2014), who indicated that the radioactivity of ${ }^{226} \mathrm{Ra},{ }^{238} \mathrm{U},{ }^{232} \mathrm{Th}$ and ${ }^{40} \mathrm{~K}$ was measured in the fly ashes from thermal power stations in India enriched with the radionuclides. Compared to the activity concentrations of Greece fly ashes ranging from 142 to $605 \mathrm{~Bq} \mathrm{~kg}^{-1}$ for ${ }^{226} \mathrm{Ra}$, from 263 to $950 \mathrm{~Bq} \mathrm{~kg}^{-1}$ for ${ }^{238} \mathrm{U}$ and from 204 to $382 \mathrm{~Bq} \mathrm{~kg}^{-1}$ for ${ }^{40} \mathrm{~K}$ (Papastefanou 2008), those of all fly ashes were lower for ${ }^{226} \mathrm{Ra}$ and ${ }^{238} \mathrm{U}$, but higher for ${ }^{40} \mathrm{~K}$. The $\mathrm{A}_{\text {eff }}$ values of Pha Lai, Mong Duong I, Mong Duong II, Ha Khanh and Ninh Binh were 310, 264, 256, 197 and $277\left(\mathrm{~Bq} \mathrm{~kg}^{-1}\right)$, respectively. These values were found to be lower than the recommended limit for building materials of $370 \mathrm{~Bq} \mathrm{~kg}^{-1}$ (TCVN 10302:2014).

TABLE 4. Chemical composition (\%) of the fly ashes

\begin{tabular}{lcccccccccccc}
\hline Fy ash & $\mathrm{SiO}_{2}$ & $\mathrm{Al}_{2} \mathrm{O}_{3}$ & $\mathrm{Fe}_{2} \mathrm{O}_{3}$ & $\mathrm{P}_{2} \mathrm{O}_{5}$ & $\mathrm{~K}_{2} \mathrm{O}$ & $\mathrm{CaO}$ & $\mathrm{MgO}$ & $\mathrm{MnO}$ & $\mathrm{TiO}_{2}$ & $\mathrm{Na}_{2} \mathrm{O}$ & $\mathrm{H}_{2} \mathrm{O}-$ & $\mathrm{LOI}^{*}$ \\
\hline Pha Lai & 57.02 & 23.82 & 4.69 & 0.13 & 6.56 & 0.81 & 1.16 & 0.04 & 0.78 & 0.09 & 0.35 & 4.36 \\
Mong Duong I & 44.04 & 24.72 & 4.20 & 0.12 & 5.52 & 6.57 & 1.28 & 0.04 & 0.70 & 0.22 & 1.64 & 10.76 \\
Mong Duong II & 54.25 & 25.02 & 4.71 & 0.16 & 6.76 & 0.91 & 1.22 & 0.04 & 0.78 & 0.16 & 0.58 & 5.24 \\
Ha Khanh & 39.78 & 22.25 & 4.49 & 0.13 & 4.97 & 1.57 & 1.39 & 0.04 & 0.74 & 0.12 & 17.75 & 6.61 \\
Ninh Binh & 37.41 & 17.39 & 5.61 & 0.16 & 5.16 & 1.21 & 1.11 & 0.06 & 0.63 & 0.17 & 14.02 & 16.91 \\
\hline
\end{tabular}

*Loss of Ignition. Data given are means of three replicates

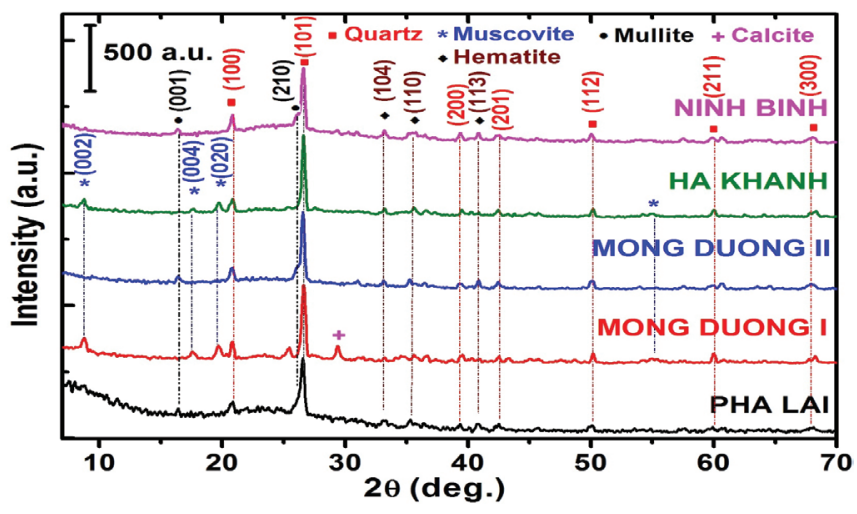

FIGURE 3. XRD patterns of the fly ashes 


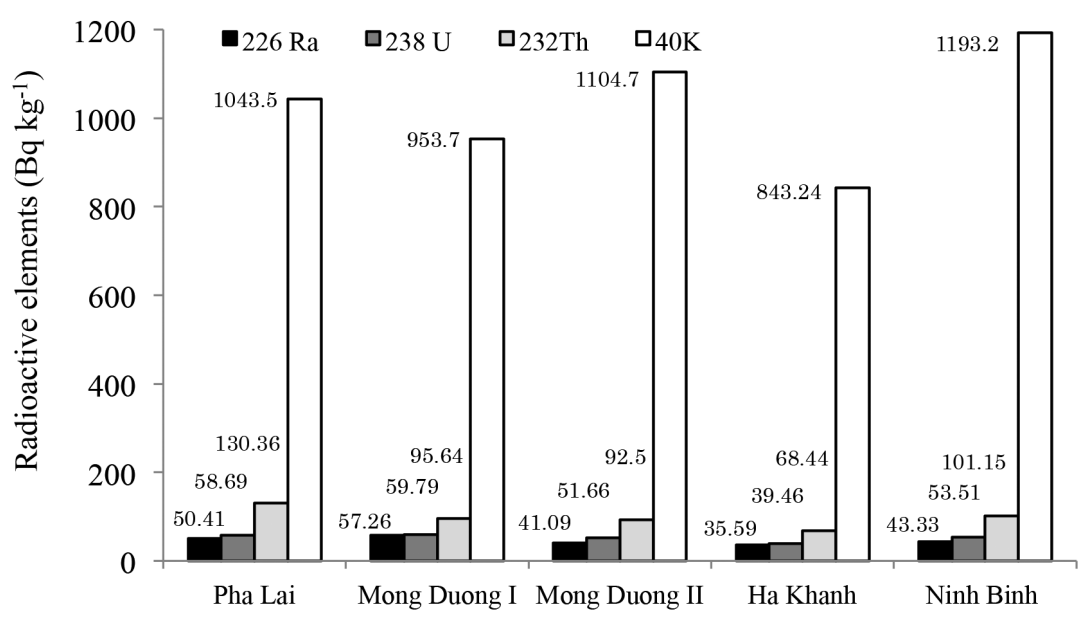

FIGURE 4. Specific activities of radioactive elements $\left(\mathrm{Bq} \mathrm{kg}^{-1}\right)$ in the fly ashes

\section{POTENTIAL RELEASE OF TRACE ELEMENTS}

The concentrations of trace elements in the TCLP extracts from the fly ashes (Table 5) were lower than the soluble threshold limit concentrations (STLC) as set by the USEPA (Testa 1997). In fact, the TCLP in the field leaching from the fly ash-amended soil may be a slow process (Ghodrati et al. 1995), the concentrations of trace elements released at any one time therefore would be much lower than the values determined in the TCLP. Furthermore, the earlier studies on the fly ash-amended soils show that trace element leaching was very low and unlikely to affect ground water quality (Ghodrati et al. 1995). However, the field trials are important to provide additional information about the beneficial reuse of fly ashes as sandy soil amendments.

\section{EFFECT OF FLY ASH AMENDMENT ON THE HYDRAULIC CONDUCTIVITY OF SANDY SOIL}

As mentioned before, sandy soils pose a challenge for water management due to high hydraulic conductivities (Pathan et al. 2001). Therefore, the additives with low hydraulic conductivities could be expected to overcome this challenge. As shown in Table 6, the hydraulic conductivities of the fly ashes ranged from 1.4 to 1.7 $\mathrm{mm} \mathrm{h}^{-1}$ and were 93-113 fold lower compared to the sandy soil. The differences in the hydraulic conductivity among the fly ashes may be due to the differences in particle size distributions. The amendment of the fly ashes into the sandy soil significantly reduced the hydraulic conductivity of soil even about 20 -fold lower at the $5 \%$ (w/w) fly ash rate. Chang et al. (1977) found that flyash amendment increased the water-holding capacity of sandy soils by $8 \%$, which in turn caused improvement in hydraulic conductivity. Besides, the plant-available water increased progressively with each larger amendment of fly ash (Figure 5). The amendment of $10 \%$ (w/v) fly ashes to the sandy soil increased the plant available water content about 1.6 times. It may be due to the incorporation of the fine-sized particles of fly ash leading to increased total porosity and surface area. Taylor and Schumann (1988) fly-ash had been shown to increase the amount of plant available water in sandy soils. Other similar results have also been found in the previous studies which showed that the amendment of fly ash to sandy soils has increased the water-holding capacity and the plant-available water at field capacity and down to the wilting point as the soil dries (Aitken et al. 1984; Campbell et al. 1983; Chang et al. 1977; Gangloff et al. 2000).

TABLE 5. Concentrations of trace elements in TCLP extracts $\left(\mathrm{mg} \mathrm{L}^{-1}\right)$ from the fly ashes and sandy soil

\begin{tabular}{|c|c|c|c|c|c|c|c|c|c|c|c|c|c|}
\hline \multicolumn{2}{|l|}{ Sample } & As & $\mathrm{Cd}$ & $\mathrm{Pb}$ & $\mathrm{Cu}$ & $\mathrm{Mn}$ & $\mathrm{Ni}$ & $\mathrm{Zn}$ & $\mathrm{Cr}$ & $\mathrm{Al}$ & $\mathrm{Hg}$ & $\mathrm{Fe}$ & Co \\
\hline \multirow{5}{*}{ Fly ash } & Pha Lai & 0.219 & 0.002 & 0.020 & 1.103 & 0.137 & 0.030 & 2.205 & 0.102 & 16.658 & 0.065 & 3.864 & 2.130 \\
\hline & Mong Duong I & 0.687 & 0.001 & 0.014 & 0.119 & 0.433 & 0.051 & 3.103 & 0.107 & 18.748 & 0.067 & 9.145 & 0.142 \\
\hline & Mong Duong II & 0.164 & 0.002 & 0.033 & 0.024 & 0.273 & 0.101 & 1.371 & 0.107 & 12.410 & 0.116 & 3.835 & 2.883 \\
\hline & Ha Khanh & 0.105 & 0.002 & 0.065 & 0.129 & 0.413 & 0.089 & 1.164 & 0.031 & 36.112 & 0.109 & 2.081 & 4.177 \\
\hline & Ninh Binh & 0.112 & 0.265 & 0.017 & 0.073 & 0.314 & 0.066 & 2.534 & 0.077 & 23.786 & 0.231 & 4.165 & 4.274 \\
\hline \multicolumn{2}{|c|}{ Sandy soil } & ND & ND & ND & 0.001 & 0.121 & 0.002 & 1.842 & 0.003 & 3.912 & ND & 1.021 & 0.001 \\
\hline \multicolumn{2}{|c|}{ STLC levels* } & 5 & 1 & 5 & 25 & NA & 20 & 250 & 5 & NA & 0.2 & NA & 80 \\
\hline
\end{tabular}

"Soluble threshold limit concentration (see Testa 1997); ND: Not detected $\left(<0.001 \mathrm{mg} \mathrm{L}^{-1}\right)$. Data given are means of three replicates 
TABLE 6. Hydraulic conductivity $\left(\mathrm{mm} \mathrm{h}^{-1}\right)$ in the fly ashes, sandy soil and their mixtures

\begin{tabular}{cccccc}
\hline $\begin{array}{c}\text { Fly ash incorporation } \\
(\%, \mathrm{w} / \mathrm{w})\end{array}$ & Pha Lai & Mong Duong I & Mong Duong II & Ha Khanh & Ninh Binh \\
\hline 0 & & $158.8 \pm 1.25$ & & \\
\hline 5 & $7.2 \pm 0.21$ & $7.3 \pm 0.22$ & $7.1 \pm 0.15$ & $7.5 \pm 0.25$ & $7.3 \pm 0.26$ \\
10 & $5.7 \pm 0.33$ & $5.4 \pm 0.15$ & $5.3 \pm 0.22$ & $5.5 \pm 0.20$ & $5.6 \pm 0.18$ \\
20 & $3.1 \pm 0.11$ & $3.2 \pm 0.12$ & $3.1 \pm 0.10$ & $3.5 \pm 0.16$ & $3.4 \pm 0.10$ \\
50 & $1.6 \pm 0.01$ & $1.7 \pm 0.02$ & $1.7 \pm 0.04$ & $1.8 \pm 0.03$ & $1.6 \pm 0.05$ \\
\hline 100 & $1.5 \pm 0.05$ & $1.6 \pm 0.06$ & $1.4 \pm 0.04$ & $1.7 \pm 0.06$ & $1.5 \pm 0.02$ \\
\hline LSD $_{(0.05)}$ & 2.11 & 1.86 & 2.00 & 1.62 & 1.92 \\
\hline
\end{tabular}

Data given are means of three replicates \pm standard errors. ANOVA was conducted on the data set (significance level $p<0.05$ ) and means compared using the LSD

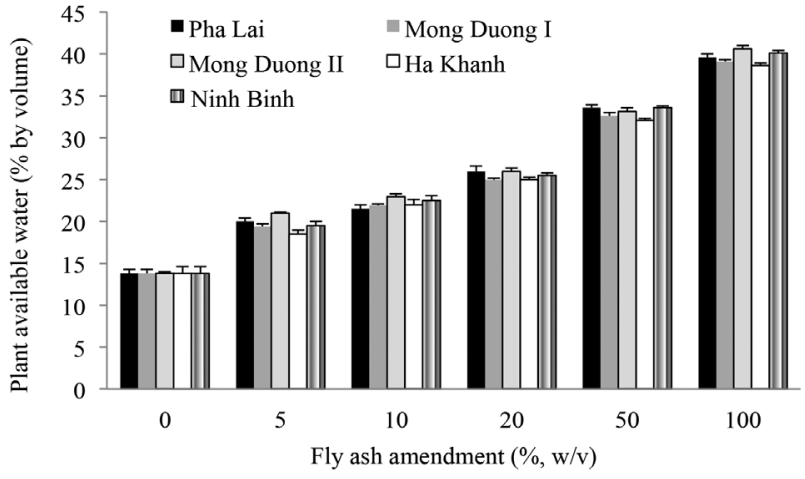

FIGURE 5. Effect of the fly ashes amended at different rates $(\%, w / w)$ with the sandy soil on the plant-available water (-5 to $-1500 \mathrm{KPa}$ matric potentials)

\section{CONCLUSION}

Although there were some differences in the physicochemical and mineralogical characteristics among the fly ashes, they all were comprised primarily of fine sandand silt-sized particles with the low bulk densities. Their values of $\mathrm{pH}, \mathrm{EC}$ and $\mathrm{CEC}$ were higher compared to the sandy soil. Almost all essential macro-and micro-nutrients were presented in the fly ashes. The potential to release trace elements from the fly ashes was below regulatory guidelines. The amendment of fly ashes to the sandy soil led to the substantial decrease in the hydraulic conductivity but the increase in the plant-available water contents of the sandy soil. It is recommended that the fly ashes have great potential to be used as amendments for improving soil texture, bulk density, water-holding capacity, acidity, availability of nutrients and biological properties of the sandy soil, ultimately improving crop yields and enhancing food security.

\section{ACKNOWLEDGEMENTS}

This research is funded by Vietnam National Foundation for Science and Technology Development (NAFOSTED) under grant number: 105.08-2014.31.

\section{REFERENCES}

Adriano, D.C., Page, A.L., Elseewi, A.A., Chang, A.C. \& Straughan, I. 1980. Utilization and disposal of fly ash and other coal residues in terrestrial ecosystems: A review. Journal of Environmental Quality 9: 333-344.

Ahmaruzzaman, M. 2010. A review on the utilization of fly ash. Progress in Energy and Combustion Science 36: 327-363.

Aitken, R.L., Campbell, D.J. \& Bell, L.C. 1984. Properties of Australian fly ashes relevant to their agronomic utilisation. Australian Journal of Soil Research 22: 443-453.

Asokan, P., Saxena, M. \& Asolekar, S.R. 2005. Coal combustion residues environmental implications and recycling potentials. Resources, Conservation and Recycling 43: 239-262.

Basu, M., Pande, M., Bhadoria, P.B.S. \& Mahapatra, S.C. 2009. Potential fly-ash utilization in agriculture: A global review. Progress in Natural Science 19: 1173-1186.

Bhangare, R.C., Tiwari, M., Ajmal, P.Y., Sahu, S.K. \& Pandit, G.G. 2014. Distribution of natural radioactivity in coal and combustion residues of thermal power plants. Journal of Radio Analytical and Nuclear Chemistry 300: 17-22.

Blake, G.R. \& Hartge, K.H. 1986. Bulk density. In Methods of Soil Analysis, Part 1, 2nd ed., Klute, A. (Ed.), Agron. Monogr. 9., ASA and SSSA, Madison, Wisconsin. pp. 363-375.

Campbell, D.J., Fox, W.E., Aitken, R.L. \& Bell, L.C. 1983. Physical characteristics of sand amended with fly ash. Australian Journal of Soil Research 21: 147-154.

Cetin, S. \& Pehlivan, E. 2007. The use of flyash as a low cost, environmentally friendly alternative to activated carbon for the removal of heavy metals from aqueous solutions. Colloids and Surfaces A: Physicochemical and Engineering Aspects 298: 83-87.

Chang, A.C., Lund, L.J., Page, A.L. \& Warneke, J.E. 1977. Physical properties of fly ash amended soils. Journal of Environmental Quality 6: 267-270.

Chansiriwat, W., Tanangteerapong, D. \& Wantala, K. 2016. Synthesis of zeolite from coal fly ash by hydrothermal method without adding alumina and silica sources: Effect of aging temperature and time. Sains Malaysiana 45(11): 1723-1731.

Fediuk, R.S.\& Yushin, A.M. 2015. The use of fly ash the thermal power plants in the construction. IOP Conf. Series: Materials Science and Engineering 93: 012070.

Femández-Jiménez, A. \& Palomo, A. 2005. Microstructure development of alkali-activated fly ash cement: Adescriptive model. Cement and Concrete Research 35(6): 1204-1209.

Fisher, G.L., Chang, D.P.Y. \& Brummer, M. 1976. Fly ash collected from electrostatic precipitators: Microcrystalline 
structures and the mystery of the spheres. Science 129: 553-555

Gangloff, W.J., Ghodrati, M., Sims, J.T. \& Vasilas, B.L. 2000. Impact of fly ash amendment and incorporation method on hydraulic properties of a sandy soil. Water, Air \& Soil Pollution 119: 231-245.

Ghodrati, M., Sims, J.T. \& Vasilas, B.L. 1995. Evaluation of fly ash as a soil amendment for the Atlantic Coastal Plain: I. Soil hydraulic properties and elemental leaching. Water, Air \& Soil Pollution 81: 349-361.

Hodgson, D.R. \& Holliday, R. 1966. The agronomic properties of pulverized fuel ash. Chemistry \& Industry 20: 785-790.

Inam, A. 2007. Use of flyash in turnip (Brassica rapa L.) cultivation. Pollution Research 26(1): 39-42.

Iyer, R.S. \& Scott, J.A. 2001. Power station fly ash- A review of value-added utilization outside of the construction industry. Resources, Conservation and Recycling 31(3): 217-228.

Izidoro, J.C., Fungaro, D.A., Santos, F.S. \& Wang, S. 2012. Characteristics of Brazilian coal fly ashes and their synthesized zeolites. Fuel Processing Technology 97: 38-44.

Jala, S. \& Goyal, D. 2006. Fly ash as a soil ameliorant for improving crop production-A review. Bioresource Technology 97: 1136-1147.

Klute, A. \& Dirksen, C. 1986. Hydraulic conductivity and diffusivity: Laboratory methods. In Methods of Soil Analysis, Part 1, 2nd ed., Klute, A. (Ed.), Agron. Monogr. 9., ASA and SSSA, Madison, Wisconsin. pp. 687-734.

Kishor, P., Ghosh, A.K. \& Kumar, D. 2010. Use of flyash in agriculture: A way to improve soil fertility and its productivity. Asian Journal of Agricultural Research 4(1): 1-14.

Kolay, P.K. \& Bhusal, S. 2014. Recovery of hollow spherical particles with two different densities from coal fly ash and their characterization. Fuel 117: 118-124.

Ma, X., Zhang, Z. \& Wang, A. 2016. The transition of fly ashbased geopolymer gels into ordered structures and the effect on the compressive strength. Construction and Building Materials 104: 25-33.

Nizar, I.K., Mustafa, Al Bakri., A.M., Rafiza, A.R., Kamarudin, H., Alida, A. \& Zarina, Y. 2014. Study on physical and chemical properties of fly ash from different area in Malaysia. Key Engineering Materials 594-595: 985-989.

Okoye, F.N., Durgaprasad, J. \& Singh, N.B. 2015. Mechanical properties of alkali activated fly ash/kaolin based geopolymer concrete. Construction and Building Materials 98: 685-691.

Onutai, S., Jiemsirilers, S., Thavorniti, P. \& Kobayashi, T. 2015. Aluminium hydroxide waste based geopolymer composed of fly ash for sustainable cement materials. Construction and Building Materials 101: 298-308.

Pandey, V.C. \& Singh, N. 2010. Impact of fly ash incorporation in soil systems. Agriculture, Ecosystems \& Environment 136: 16-27.

Papastefanou, C. 2008. Radioactivity of coals and flyashes. Journal of Radioanalytical and Nuclear Chemistry 275(1): 29-35.

Pathan, S.M., Aylmore, L.A.G. \& Colmer, T.D. 2003. Properties of several fly ash materials in relation to use as soil amendments. Journal of Environmental Quality 32: 687-693.

Pathan, S.M., Aylmore, L.A.G. \& Colmer, T.D. 2001. Fly ash amendment of sandy soil to improve water and nutrient use efficiency in turf culture. Research Journal 9: 33-39.

Ram, L.C. \& Masto, R.E. 2014. Fly ash for soil amelioration: A review on the influence of ash blending with inorganic and organic amendments. Earth-Science Reviews 128: 52-74.
Ram, L.C. \& Masto, R.E. 2010. An appraisal of the potential use of fly ash for reclaiming coal mine spoil. Journal of Environmental Management 91: 603-617.

Ram, L.C., Srivastava, N.K., Jha, S.K., Sinha, A.K., Masto, R.E. \& Selvi, V.A. 2007. Management of lignite fly ash for improving soil fertility and crop productivity. Environmental Management 40: 438-452.

Rashad, A.M. 2015. A brief on high-volume Class F fly ash as cement replacement - A guide for Civil Engineer. International Journal of Sustainable Built Environment 4: 278-306.

Skousen, J., Paul Ziemkiewicz, Z. \& Yang, J.E. 2012. Use of coal combustion by-products in mine reclamation: Review of case studies in the USA. Geosystem Engineering 15: 71-83.

Summers, R., Clarke, M., Pope, T. \& O’Dea, T. 1998. Western Australian fly ash on sandy soils for clover production. Communications in Soil Science and Plant Analysis 29: 2757-2767.

Swamy, R.N. \& Lambert, G.H. 1981. The microstructure of Lytag aggregate. The International Journal of Cement Composites and Lightweight Concrete 3(4): 273-282.

Taylor, E.M. \& Schumann, G.E. 1988. Flyash and lime amendment of acidic coal soil to aid revegetation. Journal of Environmental Quality 17: 120-124.

TCVN 4406-87. Vietnamese Standard on Soil-Method for determination of total of exchange calcium and magnesium. Ministry of Science, Technology and Environment of the Socialist Republic of Vietnam.

TCVN 6498:1999 (ISO 11261:1995). Vietnamese Standard on Soil quality-Determination of total nitrogen: Modified Kjeldahl method. Ministry of Science, Technology and Environment of the Socialist Republic of Vietnam.

TCVN 6642:2000 (ISO 10694:1995). Vietnamese Standard on Soil Quality: Determination of Organic and Total Carbon After Dry Combustion (Elementary Analysis). Ministry of Science, Technology and Environment of the Socialist Republic of Vietnam.

TCVN 5256:2009. Vietnamese Standard on Soil Quality: Method for Determination of Bio-Available Phosphorus. Ministry of Science and Technology of the Socialist Republic of Vietnam.

TCVN 8568:2010. Vietnamese Standard on Soil Quality: Method for Determination of Cation Exchange Capacity (CEC) by Ammonium Acetate Method. Ministry of Science and Technology of the Socialist Republic of Vietnam.

TCVN 8662:2011. Vietnamese Standard on Soil Quality: Method for Determination of Bio-Available Potassium. Ministry of Science and Technology of the Socialist Republic of Vietnam.

TCVN 10302:2014. Vietnamese Standard on Activity Admixture Fly Ash for Concrete, Mortar and Cement. Ministry of Science and Technology of the Socialist Republic of Vietnam.

Testa, S.M. 1997. Laboratory considerations. In The Reuse and Recycling of Contaminated Soil, edited by Testa, S.M. New York: Lewis Publishers. pp. 81-101.

Ukwattage, N.L., Ranjith, P.G. \& Bouazza, M. 2013. The use of coal combustion fly ash as a soil amendment in agricultural lands (with comments on its potential to improve food security and sequester carbon). Fuel 109: 400-408.

USEPA(United States Environmental Protection Agency). 1992. Method 1311: Toxicity Characteristic Leaching Procedure. Test Methods for Evaluating Solid Waste Physical/Chemical Methods. Publ. SW-846. EPA, Washington, DC.

USDA (United States Department of Agriculture). 2017. Soil Survey Manual. Soil Science Division Staff. Agriculture Handbook No. 18. 
Yao, Z.T., Ji, X.S., Sarker, P.K., Tang, J.H., Ge, L.Q., Xia, M.S. \& Xi, Y.Q. 2015. A comprehensive review on the applications of coal fly ash. Earth-Science Reviews 141: 105-121.

Yao, Z.T., Xia, M.S., Sarker, P.K. \& Chen, T. 2014. A review of the alumina recovery from coal fly ash, with a focus in China. Fuel 120: 74-85.

Zheng, Y.J., Jensen, A.D., Windelin, J. \& Jensen, F. 2012. Review of technologies for mercury removal from flue gas from cement production processes. Progress in Energy and Combustion Science 38: 599-629.

Le Van Thien*, Ngo Thi Tuong Chau, Le Thi Tham Hong \& Nguyen Thu Trang

Vietnam National University

University of Science

334 Nguyen Trai, Thanh Xuan

Hanoi

Vietnam
Hiroyuki Futamata

Research Institute of Green Science and Technology

Shizuoka University, Suruga-ku

Shizuoka, 422-8529

Japan

*Corresponding author; email: levanthien@hus.edu.vn

Received: 4 December 2017

Accepted: 6 February 2019 